Article

\title{
Gender and sustainability: Learning from women's farming in the global South
}

\author{
Tricia Glazebrook ${ }^{1 *}$, and Emmanuela Opoku ${ }^{2}$ \\ 1 School of Politics, Philosophy and Public Affairs, Washington State University, Pullman, WA 99164, USA; \\ 2 Department of Environmental Science, university for Development Studies, Navrongo, Ghana; \\ EmmanuelaOpoku@my.unt.edu \\ * Correspondence: patricia.glazebrook@wsu.edu; Tel.: +1-509-335-2544
}

\begin{abstract}
Africa was the only continent not to achieve the 2015 Millennium Development Goal of $50 \%$ poverty reduction. This paper asks whether Africa will fare better in meeting Sustainable Development Goals (SDGs) addressing poverty and hunger by 2030. To answer this question we examine literature, including our field research published over the last thirteen years. We find that 'sustainable development' is a failed concept immersed in the contemporary global economic system that favors growth over ecosystem stability and patriarchal systems of governance that undervalue women's capacity for sustainability in their care-work as food providers. We examine barriers to women's farming (climate change, gender bias, limited access to land, technology, finance) and provide examples of women's innovative strategies for overcoming these barriers in their care practices toward family and community well-being and ecosystem health. We conclude that sustainability is only possible through transformation of thinking away from approaches that value profit over people and ecosystems and toward gender-based approaches for achieving the goals laid out in the SDGs through holistic, integrative systems of ecosystem fit.
\end{abstract}

Keywords: sustainability; Sustainable Development Goals; Africa/Ghana; women and gender; agriculture; food security; climate change; capital economics; patriarchal governance; care labor/logics/practices

\section{Introduction}

The first 2030 Sustainable Development Goal (SDG1) aims to end poverty and the second (SDG2) aims to end hunger [1] (pp. 14-16). Africa was the only continent that did not achieve the 2015 Millennium Development Goal to cut poverty by 50\% [2]. Hunger and poverty are inherently linked [3] (pp. 442-3). As well as being seemingly trapped in poverty, sub-Saharan Africa (hereafter 'Africa') is extremely vulnerable to food insecurity. This paper accordingly asks whether Africa will fare any better on poverty and hunger reduction in striving to meet SDGs 1 and 2.

Two conclusions are drawn in answering this question. First, these two goals are shown to be incompatible in much of Africa for a variety of reasons. This is a significant problem because of the connection between hunger and poverty noted. Ghanaians themselves report that poverty-related stressors are their biggest challenge in meeting food security needs [4]. Secondly, neither are likely to be achieved without gender-based approaches grounded in women's agriculture. This is also deeply problematic because global economics, international and nation-state governance, and overwhelmingly the majority of local community traditional attitudes and systems are patriarchal and marginalize women. For example, women's weak land tenure renders them vulnerable to 
large-scale land acquisition that blocks local access and reduces production [5]. What is needed is transformative change in the conception of sustainability to address the challenges of capital economics and patriarchal governance.

Once current strategies for reducing poverty and hunger are shown to be unlikely to succeed because they actually generate conflict between these two entangled needs, an integrated strategy is suggested to addresses poverty and hunger together. This strategy is transformative because it displaces typical approaches with a gendered conceptual framework based on, but not limited to, women's agricultural labor. The feminization of agriculture and the feminization of poverty together have rendered women farmers vulnerable to climate impacts that exacerbate both their livelihood and food security gaps. The transformative power of gender-based value systems, however, carries the potential for sustainable practices that balance ecosystem health with food-production and livelihood. African agricultural systems of small-holder farming provide a model for just such maintenance, balance, and sustainability based on gendered approaches to food security and family care.

\section{Materials and Methods}

Literature review and field research are the primary methods used. The literature review includes material from academic research using peer-reviewed articles in a diverse array of development, agriculture, science, gender-based and other journals; United Nations websites, including the General Assembly Decision and progress report on the SDGs, the Food and Agriculture Organization (FAO), the Intergovernmental Panel on Climate Change (IPCC), the UN Development Program (UNDP), the World Commission on Environment and Development (WCED), and the World Food Programme (WFP); nation-state government and non-governmental organizations' websites, including the International Monetary Fund (IMF) and World Bank; and online media sources.

On-the-ground examples are also used from locations in the global South with focus on Ghana. We synthesize longitudinal research in published outcomes of completed projects toward a broader assessment of the on-going, continually growing challenges women farmers face and the resilience and orientation they bring to their agriculture in their battle to meet family food security needs. The next section explains why Ghana provides an informative focal point for analysis.

\section{Ghana}

Ghana provides a focal example of the situation of women farmers working in similar conditions. Its political stability enables longitudinal research that allows tracking of emerging, developing and evolving conditions distinct from anomalous events. The Sudan-Savanna extends from Africa's west coast to well into East Africa and Ghana shares this ecosystem with multiple countries.

As is common in the global South, Ghana's population relies on its farmers. They are $52 \%$ of Ghana's work force and provide over $90 \%$ of what Ghanaians eat [6]. Just under a quarter of Ghana's total land $\left(58,000 \mathrm{~km}^{2}\right)$ is cultivated, though well over half $(57 \%)$ is classified as agricultural. Only 110 $\mathrm{km}^{2}$ (11,000 hectares), i.e. less than $2 \%$, are under irrigation [6], so Ghanaian farmers rely almost 
entirely on rains. This means they grow once a year in the rainy season, roughly April to October in the north and March to November in the south, though they typically plant some fields more than once. For example, they women grow early millet (Pennisetum glaucum, also known as P. typhoides) (Ghana's $4^{\text {th }}$ most important cereal [7] and then plant the field again, and also bambara beans (Vigna subterranean [8] (also known as garbonzo beans or chickpeas) as a nitrogen fix in preparation for planting something else [9].

Ghana is moreover informative for assessing progress on poverty and hunger because agriculture plays such an important role in Ghana's poverty alleviation. In 2017, agriculture contributed 20\% of Ghana's GDP [10]. In 2018, increase in the proportion of agricultural contribution to export earnings (40\%) and GDP (54\%) [6] assisted in Ghana attaining low-middle income status in World Bank ranking [11]. Ghana accordingly looks like just the kind of success story the FAO 2018 Regional Conference promised.

The proportionate increase in agricultural contribution to GDP may not, however, mean massive growth in agriculture so much as greater decline in other sectors. Northern areas in Ghana have been experiencing on-going crop decline since at least 2007 [9] and hunger in these rural areas has rapidly increased due to climate impacts like drought, flood, and unpredictable rain patterns [9]. By 2012, three Regions were experiencing severe food insecurity in over $10 \%$ of households and moderate in $44 \%$ [12]. Adaptations include crop selection, e.g. moving to rice rather than millet because rice fares better in sporadic rainfall, and this strategy sacrifices nutrition in order to have something that will grow reliably [13]. Rice is moreover a temporary solution as it suffers $10 \%$ decline for each $1^{\circ} \mathrm{C}$ rise [14].

Women are $39 \%$ of Ghana's farmers [6] but fill between $55 \%$ and $87 \%$ of the national food basket depending on the reporting source $[15,16]$. This broad range in the data is a consequence of cascading factors. The first is that traditional economic indicators are market-based and accordingly do not track subsistence economies. This cascades into women's economic invisibility [17] that is further exacerbated by economic limitations, poor organization in governance, and gender bias in persistent social inequalities such as weak land tenue and poor access to finance, technologies, and extension services [18]. Moreover, we have shown that, regardless of a government's knowledge of women farmers' challenges and intent to address them, attempts can be stymied by international finance mechanisms [18].

For example, Ghana's first Poverty Reduction Strategy (GPRS) [15], completed in consultation with a consortium of women's groups with access for women in rural, northern areas, identified gender equity as one of its strategies to achieve its goals of sustainable, equitable growth, accelerated poverty reduction, and protection of the vulnerable and excluded. The IMF response briefly acknowledged women's poverty and vulnerability but then focused on market factors instead and returned to gender virtually entirely in terms of the education gap - women farmers were seen not as substantial food growers but sub-optimal participants in a capital economy [18]. Ghana's dependency on IMF assessments for World Bank support, as is common for low income countries, i.e. the global South, made it powerless to maintain its proposal to target women with support programs, including credit, improved technology services, and skills upgrading. The IMF approach of educating girls in preparation for their participation in the Ghanaian economy left women farmers without the support the Government of Ghana intended. 
The consequences are a substantial number of educated, unemployed young women who want paid work rather than to farm and a generation of economically invisible women obliged to continue their labor with still almost no access to finance and technology as they age during the beginning of agricultural collapse in some areas of Ghana. International finance systems allegedly supporting development in the global South have moreover generated a debt load that it is virtually impossible for Africa to free itself from.

\section{Food security, climate change, and poverty}

The question of food security in Africa is crucial because Africa is currently experiencing humanitarian crises in hunger at the intersection of poverty and climate change that together have disastrous impacts on food security. In 2015, over $98 \%$ of the 795 million people on the planet experiencing hunger were in the global South [19] (pp. 8-9). From 2014-16, over a quarter (27.7\%) of them-220 million people-were in sub-Saharan Africa [19] (p. 10). By 2018, 257 million Africans were hungry [20]. In the ten years between 2005 and 2015, nineteen of sub-Saharan Africa's fifty-four countries (experienced food crisis in at least eight years [19] (p. 27).

Yet in early 2018, José Graziano da Silva, Director-General of a UN FAO Regional Conference for Africa, announced that Africa would meet its complete eradication hunger goal by 2025, five years before the SDG deadline, through political will, better access to funding for climate resilience, and the improving global economy by means of resilient populations, empowerment of vulnerable groups, promotion of agribusiness, good governance, harmonization of national policies, and strong institutional capacities for effective implementation [21]. These are long-standing promises and strategies for reducing both hunger and poverty. Gender imbalance has created the double challenge to women of the phenomena known as the 'feminization of poverty' and the 'feminization of agriculture' that place women in the poverty and climate change nexus.

Concerning poverty, in 2017, the International Monetary Fund anticipated that sub-Saharan Africa was on the road to economic recovery because its growth in 2017 was likely to reach $2.6 \%$-a promising improvement over 2016's 1.4\% [22]. The African Development Bank (ADB) was more optimistic, assessing 2016 Gross Domestic Product growth at 2.2\% and anticipating 2017 growth at $3 \%$ and $3.7 \%$ in 2018 [23]. Yet per capita income was expected barely to increase, and in fact to decline for approximately $40 \%$ of the population, i.e. 400 million people [2]. One explanation for growth without individual income increase is that much of this development depends upon oil resources: the ADB notes, concerning West Africa, that increased growth in the region is derived from four countries' oil revenues, while decline in oil contracts in Nigeria, that accounts for $72.4 \%$ of West Africa's GDP, is holding back the overall growth figure for the region [23]. There is thus no reason to believe that this growth increase would actually alleviate poverty for many Africans. Moreover, growth after 2017 was expected to be approximately $3.25 \%$. If growth of $4.5 \%$ in the $1990 \mathrm{~s}$ was inadequate for sub-Saharan Africa to reach the 2015 poverty MDG, it seems even less likely that $3.25 \%$ growth will achieve the same poverty reduction SDG of $50 \%$ by 2030, never mind by 2025 .

In this context, sub-Saharan Africans largely rely on women's agricultural work to fill national food baskets. Agriculture is in fact the primary livelihood for 1.4 billion women globally who live in rural areas [24], and in the global South, women make up $43 \%$ of the agricultural workforce and are 
$66 \%$ of livestock keepers [25]. In Africa, given what was said above, this means that women farmers are strongly motivated to develop climate adaptations and other strategies for meeting family food security needs because food security collapse is currently a threat to women farmers in Africa who are trapped in the poverty and climate change nexus.

Concerning climate change, the IPCC's $5^{\text {th }}$ Assessment Report (AR5) identifies food insecurity as a key climate risk for developing countries [26] (p. 13). Africa's agricultural productivity is expected with 'high confidence' to be near medium risk by 2030 and well into medium risk by 2080, even with adaptations, if the Global Mean Surface Temperature rise above pre-industrial levels (GMST) is $2^{\circ} \mathrm{C}$, and at very high risk by 2080 at a GMST of $4^{\circ} \mathrm{C}$ [26]. Vulnerability differs according to multidimensional inequalities, including gender, and the greatest vulnerability is to those who are marginalized socially, economically, culturally, politically, and institutionally [26] (p. 6). Sub-Saharan women farmers are marginalized in all these ways and must struggle with weak land tenure, limited access to finance, resources, technology, and extension services, and persistent social inequalities that hamper their agricultural capacity and productivity [24].

The IPCC makes several recommendations to build climate resilience [26] (p. 2), including technological adaptations and adaptations in agroforestry. Women's limited opportunity to access technologies, however, precludes their use of such things as early warning systems of weather and other threats, and women are often excluded from agroforestry [9]. Recommendation to improve smallholder access to bank accounts and credit is not useful for women when local decision-making remains gender biased, which is the primary reason women do not already have access to bank accounts or credit. Women could benefit from IPCC recommendation of alternative income and diversified livelihoods, though generally women already do so as much as they can, e.g. in Ghana, they often process shea butter, weave baskets, and market spice mixes they make. In short, IPCC recommendations reinforce existing systems that do not serve women well, rather than proposing substantive change. In the case of climate change, substantive change would mean meeting women farmers' needs through immediate strong action to mitigate greenhouse gas emissions and invest in renewables that would also benefit ecosystems, people, and cohabitant species throughout the planet.

Like the IMF, as noted above, however, the IPCC works toward in-system fixes when in fact the system itself needs fixing. The solutions put forward at the FAO Regional Conference have in fact made little, if any, progress. Masses of literature that provide warnings, propose solutions, and give significant attention to gender and women's agriculture, as well as decades of structural readjustment, substantial investment by international systems of global finance, and diverse interventions by international bodies and NGOs have not been able to resolve the increasing connection between the feminization of agriculture and the feminization of poverty or slow the decay and imminent collapse of Africa's agricultural systems. More than two years after the FAO Conference, on June 5 2020, the UN Development Program reported that Africa still needs 'resilient agriculture and smarter food systems' as it faces multiplying crises of climate change and plagues of locusts exacerbated by COVID-19, that together could lead to as many as 300,000 people starving daily [27]. Addressing Africa's hunger does not seem possible through the typical strategies when for decades climate impacts have increasingly eaten away at women farmers' food security. 
We examine what transformational change might look like in multiple parts. First, we show that 'sustainable development' corrupts the concept of sustainability by favoring growth over system stability. We then propose an alternative understanding of sustainability using the four categories of 'ecosystem services.' Next, we show that the SDGs, much like the IMF and IPCC, work within existing systems that need transformative change if the Goals are to be reached, followed by discussion of the limitations of SDGs for addressing women farmers' needs. Fourth, we provide examples of women's successes at the community level to address poverty and hunger and examine factors contributing to their success. Fifth, we propose gender-centered systems of care in labors practice to support sustainable agriculture. Agriculture is our focus because hunger and food security crises in Africa are pressing humanitarian issues, but our proposal is not limited to agriculture because it entails systemic transformation. Finally, we summarize our results and provide a brief discussion.

\section{Sustainable development}

Sustainability is a contested term. This complexity is argued to be advantageous because sustainability is a contemporary global challenge that is in crisis and the concept must evolve through the diversity of its contexts and uses as its meaning is worked out - the word must always open for rethinking [28] (p. 225). We argue, however, that the concept of 'sustainability' has been significantly damaged by its appropriation into the term 'sustainable development.' This term is an oxymoron in that 'sustainable' and 'development' are inherently contradictory. 'Sustainability' entails balance over the long term, while 'development' entails growth. In global economics, growth trumps stability.

The concept of 'sustainable development' first emerged from economics debates in the 1970s when intergenerational justice became an issue in case resource depletion denied future generations their right to an equitable resource base. This lead to quantitative assessments of resource management, i.e. a stocktaking of reserves that looks forward to the future, and the idea of conservation to keep from depleting or exhausting those reserves [29, 30]. In consequence, UN Secretary-General Javier Pèrez de Cuèllar invited Gro Harlem Brundtland, formerly President of Norway, to examine environmental impacts of global development. The resulting 1987 document, Our Common Future: Report of the World Commission on Environment and Development, became popularly known as the Brundtland Report that defines 'sustainable development' as 'the kind of development that meets the needs of the present without compromising the ability of future generations to meet their own needs' [31]. It has three pillars: economic, environmental and social, also known and 'people, planet, and profits.' The Report also identifies two key concepts: need, that prioritizes essential needs of the world's poor, and natural limits, that acknowledges the finitude of ecosystem capacity to satisfy unlimited human consumption. We argue that the economic pillar has been increasingly prioritized in subsequent development activities at the expense of ecosystems and large numbers of the planet's inhabitants, including human, animal, and other life.

The 1992 Rio Earth Summit that focused on contemporary hardships affecting the global poor adapted the concept of 'sustainable development' to distributive justice issues across peoples and cultural groups in the present. This became known as 'the welfare definition' of sustainable 
development because it interprets 'needs and nature's limits' in terms of improvement of human welfare. This definition is humanitarian in aim but implies, just as anthropocentrically as the original future orientation, that natural entities, i.e. the 'environmental' pillar, are reducible to human resources. Both approaches accordingly favor human needs over natural limits. As capital evolved into consumer culture, disposability and built in obsolescence, for example, created virtually unlimited demand for resource exploitation, contrary to the idea of conservation that recognizes natural limits.

Conservation does not treat all humans the same, however, and has served in policy attempts to protect ecosystems by removing the human factor. For example, as shown elsewhere [32], outside a Safari Park in South Africa, a tour guide issued assurance that inhabitants had been removed and were not a threat to the park. The policy approach did not trust indigenous residents or their traditional ecological knowledge systems to steward the area and its animal inhabitants responsibly. The fact, however, that there is something that the indigenous cultural groups might be feared to destroy is actually evidence that they participated in the local ecosystem sustainably for as long as they lived there. 'Conservation' in this context actually means appropriating the land and animals as resources for the African tourist industry in which wildlife watching constitutes $80 \%$ of sales of tourist travel annually and is estimated to collect $\$ 90$ million USD yearly in South Africa, for example, just from visitors to such protected areas [33] (p. 25).

This is not a significant amount for a country that had a GDP well over \$350 billion USD in 2019 [34] but it demonstrates that appropriation of ecosystems, species, and indigenous people into global economic systems, with the treatment of each depending upon its place in that system. That is, the ecosystem and species are valued and protected for the enjoyment of visitors often form the global North, while locals seem disposable as they are reduced to living in a small shanty town just outside the park's gates.

The World Tourist Organization aims at sustainability by briefing African governments and the broader international community on Africa's 'on-going poaching crisis driven by a dramatic increase in the illicit trade in wildlife products' [33] (p. 2). Yet a bigger picture reveals that tourism and poaching function in the same economic system that prioritizes individuals' profit over species and system health. The removal of indigenous residents, for whom the land was a subsistence resource, may have turned to unsustainable poaching because they have lost their home and livelihood and left obliged to fend for themselves. Their absence may also make poaching easier by eliminating a consistent resident presence. Conservation practices may actually undermine their goal by aiming to displace inherent, complex, always moving ecosystem balance.

Sustainability as ecosystem management to stay within natural limits is thus dwarfed by economic interests that are inherently anthropocentric in reducing nature to resource stockpiles and that assume human interventions can manage systems better than natural processes. Many cultures have collapsed because they destroyed their ecosystem base [35]. Rise of cultures in different ecosystems, as in the past, no longer seems likely if global ecosystem disruption by climate change is not soon addressed. A new approach is needed.

\section{Ecosystem services}


'Ecosystem services' has emerged as another approach to understanding sustainability that is holistic in its prioritization of understanding how ecosystems work by considering all the activities and factors that function in an ecosystem. The UN-sponsored Millennium Ecosystem Assessment, in seeking to understand human impacts on ecosystems and people much like the Brundtland Report, identified four categories of ecosystem services: provisioning, regulating, cultural and supporting services [36]. Provisioning services are any benefit that can be drawn from nature, e.g. food, water, and medicinal plants. Regulating services have system impacts that make life possible, e.g. pollination, erosion and flood control, and carbon storage. Cultural services are the role ecosystems play in cultural identity and intellectual development, knowledge-building, and creativity. Supporting services, e.g. photosynthesis and nutrient cycling, are underlying natural processes without which provision, regulating and cultural services could not exist.

These services benefit people but the four categories also recognizes that ecosystems are complex, constantly shifting their balance, and can be durable over time, even with humans in residence. Based on assumption that ecosystems are interactive, an ecosystem services approach values things typically discarded as 'externalities' in capital systems of resource exploitation. For example, a forest is not just so many board-feet of limber but also squirrel habitat. Human survival and even thriving depends on the interconnectedness and interdependent functioning of other entities and systems that balance ecosystems for long-term stability. A focal distinction between this approach and the conservation approach is that an ecosystems services approach does not place human being above all other life but as part of a system that people participate in but do not dominate and exploit at will. Ecosystems services also value diverse traditions and knowledge systems as valid because they are informed by, understand and respect local surroundings.

Ecosystems services is accordingly not just an alternative ontology, epistemology, or method but transformative thinking that displaces the capital goal of wealth accumulation through resource and labor exploitation in favor of understanding and participating in system stability toward thriving. In other words, the concept of ecosystem services displaces the corruption of the concept of sustainability in the phrase 'sustainable development' that underwrites systems of economic growth. Instead, the concept codes sustainability as ecosystem health and longevity.

Etymologically, 'sustainability' (from the Latin sustinere, i.e. sub meaning 'under,' and tenere meaning 'to hold' but also to know, grasp, keep or maintain) means the capacity to hold up and support. The sustainable development goals cannot succeed unless they displace 'sustainable development' in favor simply of sustainability. 'Sustainable development' was originally intended to protect future generations from distributive resource injustice. The welfare interpretation aimed at equity for indigenous cultures mostly in the global South but also the North. We suggest that sustainability requires deep attention to and learning from indigenous practices, with respect in particular to agricultural practices, including water systems, located in the poverty-food security - climate change nexus. Against that transformative understanding of sustainability, we now assess the SDGs with respect to their capacity to meet the needs of women farmers in Africa.

\section{The Sustainable Development Goals}


The 2019 UN report on progress toward the SDGs notes that it has been slow, that the most vulnerable continue to suffer the most, and that global response has not been ambitious enough [37]. One reason is that meeting all the SDGs together is problematic. For example, poverty reduction depends on market-oriented intensification and increased production in agriculture that leads to market gains. Market gains, however, exacerbate women's marginalization and poverty through various forms of land tenure insecurity [38]. Moreover, market gains clash with public health (SDG 3), i.e. they correlate with increased food-related illness [39]. Evaluating progress toward SDGs can thus be deceptive. Suitable indicators must be used to assess progress towards the SDGs beyond market gains and with assessment of impacts and costs to women farmers whose subsistence agriculture is only minimally market-intended and almost universally sold 'small, small' in order only to buy school books or uniforms for children [9] .

Urbanization and urban migration are common and an on-going in Africa. In Ghana, for example, the proportion of the population in cities went from $43.8 \%$ in 2000 to 50.9\% in 2010 [40]. As populations shift, so do funding priorities. These shifts increase the challenge of achieving SDGs because urban migration often leaves rural areas neglected in development [40]. This means that women farmers' needs risk being overlooked. Urbanization also adversely affects the livelihoods of the local fringe communities [41], including agricultural. Sustainability requires that urban and rural needs and challenges are identified and managed in balance, especially in fringe communities, and that women farmers in communities are proactively included in development programs in rural communities.

Climate change further complicates the picture. Achieving SDGs 1 (poverty) and 2 (hunger) simultaneously with 13 (climate) has been shown in South Africa to be difficult because agriculture is reliant upon livestock production that is the largest CO2 emitter in the agricultural sector [42]. Livestock are significant emitters of methane that is far more powerful as a greenhouse gas than CO2. Farmers throughout Africa keep livestock, so this issue is not unique to South Africa. Ngarava et al. also found that exponential increase in agricultural income did not lead to a reduction in agricultural $\mathrm{CO} 2$ emissions and recommend adoption of renewable energy sources by farmers instead as a way of mitigating their greenhouse gas contributions. This is not helpful for women farmers whose carbon footprint is extremely low, with livestock likely being their biggest carbon emitter.

Furthermore, little is known about how implementation of CSA affects the balance needed to attain the SDGs, given the tensions and conflicts between SDGs [43]. In the meantime, working with women farmers in a climate-smart village in northern Ghana, Jagustovića et al. [44] show that women can reconcile conflicting SDGs by applying systems thinking to income-generating and tree planting activities in order to generate desirable simultaneous system-wide impact. CSA can only succeed, in fact, with local community level involvement [41] that respects and strengthens women's capacity to make judgments and bring about change through complex factor analysis and decision-making. Nonetheless, clear conceptual understanding of CSA in deeded if it is to assist in West Africa's quest to meet SDGs [45].

\section{SDGs and gender}


The SDGs also pose specific challenges to women not just with respect to attaining the SDGs but as either exclusionary of women or, worse still, as increasing women's existing challenges. Concerning exclusion, agroforestry has been shown in Climate Smart Agriculture (CSA) to increase productivity [46], but women in Ghana, for example, are often excluded from agroforestry [9].

In the articulation of SDGs by the UN General Assembly, the feminization of poverty is not mentioned in SDG 1-'women' only figures in 'men, women, and children, or 'all men and women'-despite explicit recognition at the Beijing conference in 1995 of the unique challenge of poverty to the planet's women. Women are included in SDGs 1 and 2 as having equal rights to economic resources, as well as basic services and land ownership, which is crucial in Africa where women have weak land tenure and limited access to resources, technology, and financial services. Yet women are overlooked in the technology discussions of SDG 9 and in the discussions of finance, technology, capacity building, and systemic issues in SDG 17, that mentions women only to suggest data disaggregation. SDG 17 reverts to market issues and, consistent with our claims above that global finance systems are patriarchal, neglects women's agricultural contributions to economies in the global South that could not survive without women's agriculture supporting the population [13]. In SDG 6 on water, the sanitation and hygiene point indicates 'special attention' to the needs of women and girls with respect to hygiene. Irrigation is, however, crucial to increase women's capacity to meet food security needs, especially in a changing climate that impacts women's farming consistently with unpredictable rains, regularly with drought, and sporadically with flooding.

Specifically acknowledging these challenges to women in specific SDGs rather than as collected issues in SDGs1 and 2 is crucial because institutionalized gender bias continues to marginalize women farmers with respect to irrigation and technologies in the global South where food security is largely women's responsibility and humanitarian crises in hunger are already underway. The SDG 2 aim to double agricultural productivity of 'in particular women' is not likely to succeed if the SDGs do not outline a concrete, systematic approach that acknowledges both the feminization of poverty and the feminization of agriculture throughout articulation of SDGs.

In fact, the July 2019 Report of the UN Secretary-General, António Guterres, on progress to the SDGs stated that in approximately ninety countries, women daily contribute three times more hours than men to unpaid care and domestic work, which limited their time for education, paid work and leisure, and reinforced socioeconomic gender bias and disadvantages [37]. S-G Guterres also reported women's under-representation at all levels of political leadership, with average representation in Parliaments of $24.2 \%$, a mean of $26 \%$ in elected, deliberative bodies, and $27 \%$ representation in managerial positions (up only 1\% since 2015) despite being $39 \%$ of the employed.

The most significant challenge to meeting SDGs in Africa is quite likely the undiscussed tension between oil wealth and climate impacts on women's agriculture. Ghana, for example, discovered oil offshore in 2007, first produced it in 2011, and has since developed this lucrative resource that has immense potential to benefit Ghanaians [47]. Yet oil is also recognized as a 'resource curse' because of its role as a 'windfall' resource that pushes out other industry [48], but more significantly in Africa, because of corruption [49, 50], conflict [51, 52], and environmental devastation [53]. These are, however in-system problems generated by sudden, extreme wealth and the human desire for wealth and power. A transformative approach would mean a shift in priorities at the individual, community, and global level. 
In the meantime, however, the most threatening challenge on the planet at present is climate change because, unchecked, it is moving the planet toward a mass extinction event if the GMST increases by $4^{\circ} \mathrm{C}[26]$ (p. 19). Climate change is widely recognized as impacting agriculture in Africa by causing droughts, floods and sporadic, unpredictable rainfall. Ghana is both generating the greenhouse gases that drive climate change and investing resources in climate adaptation. Oil is a major factor in African economies while food security and hunger are in crisis across the continent. This fundamental contradiction, in which the best wealth generation option for addressing poverty is also contributing to the driver of food security collapse, cannot be resolve within existing systems.

\section{Solutions}

The only real change evident now in Africa to address poverty and hunger has been initiated not from traditional 'blue-sky' policies designed by patriarchal systems of governance and finance, but from women's interventions at the community ground-level. For example, Wangari Maathai's widely known and astonishingly successful Green Belt Movement of tree-planting in Kenya has re-greened large swaths of the country and been transformative for women's empowerment, poverty alleviation, food security, ecosystem health, and climate adaptation [54]. Why did Maathai start and continue with this project? Her memoir describes the challenges and attempts to stop her from her husband, her employer, and the police [55]. Eventually, she received a Nobel Prize for her efforts, but she could not have anticipated that. This project changed thousands of women's lives and gave women hope as well as remediated land that improved their agricultural productivity and life.

In Nigeria, one way that women entrepreneurs create employment and livelihood for other women, without creating the conflicts between SDGs noted above, is by establishing recycling businesses that generate revenue by collecting waste, sorting and adding value to recyclables, and selling them on for reuse. Waste management is a massive problem in many countries in the South where infrastructure is weak and people simply discard waste in a nearby river or popular site for dumping waste, whether managed or not. Mariam Lawani, at her recycling company in Lagos, for example, explicitly works toward SDG 1 (poverty) by providing livelihoods, SDG 4 (education) by expanding skill sets, SDG 6 (sanitation) by keeping waste out of water systems, SDG 8 (employment) by creating jobs, and SDG 12 (sustainable consumption) by keeping recyclables in production systems and reducing what ends up in a dump site [56]. Though Lawani does not note it, her business also addresses SDG 2 (hunger) by providing women with a livelihood, SDG 3 (health) by reducing disease-carrying pests attracted to street waste and preventing water-system clogging that causes pooling and thus increases populations of mosquitos that carry malaria or other vector-borne diseases, as well as SDG 5 (gender equity) by empowering women, and SDG 13 (climate change) by reducing $\mathrm{CO} 2$ emissions from waste burning. Her business is contributing to nine of the seventeen SDGs simultaneously while providing an important public service.

Likewise, the women of the Deccan Development Society (DDS) in India changed their lives and fed communities by remediating land considered worthless and reviving traditional lentils and pulses that were being replaced by main-streamed crops such as basmati rice or genetically modified golden rice. India's National Biodiversity Board Committee declared the region where the DDS 
worked an agro-biodiversity heritage site $[57,58]$. Their goal was to feed their family, and to reach that goal, they cared for their animals, healed their ecosystem, and treated women members of the group who were pregnant, ill, or aging as colleagues who needed support rather than sub-optimal workers [59]. Their values favor people over profit.

The Chipko women of India are similarly known for their work defending trees that ultimately prompted India's government to legislate need for local agreement for logging and other tree protection, including a 15-year ban on commercial felling in the Uttarakhand Himalayas [60]. The primary concern for the women of the DDS and the Chipko movement is functional care for their family through sustaining their ecosystem and their community. Their work is within economic systems but also displaces the values of capital that prioritize profit in favor of their own, quite different values.

Both the DDS and the Chipko movement show that women's work has, since before the SDGs were envisioned, been working towards sustainability using an integrated, holistic strategy toward human well-being and system health. With Mariam Lawani in Nigeria also, they demonstrate that with or without the SDGs, women's labor practices build synergy to overcome poverty and hunger rather than create the division and isolation of the SDGs that struggle not to damage one goal while addressing another, e.g. threatening food security while eliminating poverty.

Gender-based approaches to sustainability therefore must recognize women's capacity as drivers of change. Women's participation in government and policy is vital for actualization of their participation not just 'at the table' but in setting the agenda by providing a combination of innovative thinking and long-standing, proven, traditional knowledge. Women can initiate and guide transformational approaches through participation in project design of poverty, hunger and climate solutions rather than inclusion only in 'after-the-fact' implementation in which decision-making imposes upon them an uninformed and thus weak or sometimes downright dysfunctional plan that is unrealistic, unnecessarily labor intensive, and inefficient in its productivity.

For example, Jakarta and Makassar City in Indonesia participate in the Gender into Urban Climate Change Initiative supported by Gender CC, an NGO that provides finance and resources to local women's groups throughout the global South for integrating women into urban climate policy, mitigation, and adaptation. Makassar City decided to green its Cambayya Subdistrict and asked women's groups to implement the Lorong Garden Program (LGP) after the planning was complete. Had the women been included in planning, they would have chosen to plant pepper plants or something else that would give them a return for their labor and be a resource for other women in the community [61]. At a 2018 workshop on the LGP, the women reported struggling with the addition to their workload [62]. These factors were overlooked in planning. Programs that do not value women's practices, that often have sustained food supplies for generations, are inefficient and can have unnecessary, problematic impacts on the women they intend to benefit.

Change is, however, possible when governance and policy systems understand that women are agents of change and value them for their knowledge rather than treating them as post hoc support staff whose voices are over-looked and their labor taken for granted. For example, at a workshop a month later in the Buloa Subdistrict of Makassar City, participants reported that they planted pepper plants in their work in the LGP [63]. The women had been heard. A large part of the Initiative 
is educating decision-makers on women's capacities, knowledge, and the value of their inclusion in project planning. This education includes creating understanding of a novel economics not based on capital or market factors but on optimizing labor conditions and outcomes practically. That is, women bring transformational change by displacing the goals of patriarchal capital with their labor practices of caring for family and community through collective, practical effort. Sustainable systems that favor care have the potential to disrupt the global inequity between South and North that is the driver of poverty and hunger.

\section{Global inequity: Capital and care}

Environmentalists must be feminists for at least six reasons [64]. Two are that that population management requires gender-just family planning based on women's health, education and livelihood, and that women's bodies are more susceptible to environmental toxins than men's. The remaining are agriculture-related. First, environmental degradation harms women's livelihood and increases women's poverty. Secondly, most of the world's farmers are women growing for subsistence. Third, because women's capacity in Africa to relocate to more fertile land is often limited, women favor sustainable practices developed over generations, such as crop rotation and turning animal waste into fertilizer, to keep the land productive. Despite marginalization, women are significant agents of ecosystem management who can contribute much to sustainability policy and practice, as we have shown in the examples above. Fourth, because women's time is constricted by a larger labor-load than men's, and because women subsistence farmers are oriented toward food security over market gains, they can, working as collectives, succeed where men's groups have failed, e.g. the DDS excelled after men's groups collapsed. Environmental movements that fail to account for women's situations and respond to their needs therefore are accordingly working against their own agenda.

According to Oxfam International, global inequality that is 'out of control' is caused by biased economic systems that exclude women while allowing billionaires who do little for society to amass huge fortunes so that today, for example, twenty-two men together hold more wealth than Africa's three-hundred and twenty six million women [65]. This inequity between the global South and North, but also between women and men, is created and enabled by Eurocentric capital systems that privilege a small group almost entirely in the global North over the majority of the planet's inhabitants-both human and non-human-in order that the few can exploit masses of people, co-habitant species, and ecosystems, at the expense of the atmosphere and the very earth itself for their own accumulation of private wealth. Ecofeminists call this systemic structure a 'logic of domination' [66].

Capital is not just an economic system but a logic that is both a way of thinking and an organizational approach to the human experience [49]. 'Economics' is in fact etymologically the 'laws of the household' from the Greek oikos (home) and nomos (law). The logic of capital understands the purpose of human existence to be the accumulation of private wealth through Darwinian competition aimed at survival of the fittest. An alternative reading of Darwin suggests, consistent with an ecosystems services approach to sustainability, that survival of the fittest entails not fight-to-the-death competition but the sustainability of functional ecosystem fit. The 
transformative strength of women's agriculture is that women's work is structured by a different logic aimed not at wealth accumulation but at care practices toward family and community thriving.

'Care' in this context does not mean emotional attachment that is a denigration in policy contexts grounded in Cartesian ideologies that privilege reason over feeling and men over women, and thereby associate men with reason and women with emotion [67] (p. 82) using an epistemologically inflated notion of objectivity [67] (p. 79). Rather, 'care' means women's activities in meeting the needs of children, family, animals, crops, community, and ecosystems in their daily practices of reproducing the material conditions of everyday living on a spectrum from the immediate necessities of food, shelter, and clothing to life-enhancing and life-valuing experiences of happiness and thriving. The point is not to idealize women farmers whose work is hard and unrelenting in its challenges but to recognize that this work requires a different logic from the capital logic of wealth acquisition.

Capital logic designs and uses technologies that enables capital by providing the tools needed to develop planetary resources for human use. Because technologies are built from scientific understanding and create objects that, as objects, appear neutral, we find that capital logic is grounded in the neutrality and indifference of objectivity. Care, however, requires partiality and valuing. Capital logic favors indifference, while logics of care require what has been identified as 'emotional intelligence' [66] that requires a different kind of feeling - a sensibility to a thing's value beyond its instrumental appropriation. For example, while visiting an Ewe village in Ghana, Glazebrook attended a three-day festival that began with an animal sacrifice in order to feed the attendees. As the chief's family circled the cow, a young man hit the cow on the face with a stick as he passed and told the poor bellowing beast to shut up. The second time he did so, a woman elder in front of him turned and chastised him severely. It is one thing ceremonially to sacrifice a life to feed people; it is another to disrespect the life that is being taken and unnecessarily brutalize it.

The logic of capital can never support sustainable development because growth is its driving principle inherent to its logic. Hence poverty and wealth are assessed on the basis of GDP growth. The global North has been shaped by a history of gendered logics of domination that turn 'sources of regeneration and renewal of life...into inert and fragmented matter, mere "raw material" to be processed into a finished product' [678] (p. 26). Nature is, however, cyclical, regenerative process. The transformative capacity of logics of care displace unlimited growth and consumption with sustainable practices that meet daily needs in ways that support ecosystem balance. Sustainability without economic growth is a transformative concept in which Africa's capacity to feed its people depends on women's agriculture.

Africa hosts approximately $9 \%$ of the estimated 570 million farms worldwide. Of these 51.3 million farms, over 41million are small holdings of less than two hectares (five acres) that are family-owned [69] (p. 25) and produce 80\% of Africa's food [70] (p. xi). Many are farmed by women who grow for subsistence to feed their family rather than to take their crop in the market. Their work is care work as they must care for their crops to get an optimal yield and care for the soil to keep it fertile. They care for their animals, their children, other family, and their community. These are labor functions that are overlooked and taken for granted in international economic systems and require a different way of thinking. We have argued that this way of thinking is transformational and has the potential to displace toxic systems of industrial agriculture and toxic thinking that irresponsibly and 
unsustainably exhausts and destroys the ecosystems that enable life. This transformational logic is a gendered thinking inherent in care practices that can also be, and in indigenous groups that follow traditional practices that respect natural systems, already is, that can be a logic practiced by men as well as women, just as women can embrace the logic and practices of unsustainable patriarchal capital. Sustainable agriculture is not the yield of mass production through industrial growing systems but of many smallholders working as part of a community.

\section{Results}

We have shown that 'sustainable development' is a false promise and that the current global economic system that makes this promise is unsustainable cannot because it is intrinsically oriented towards growth. We thus conclude that achieving the SDGs is unlikely if not impossible because the IMF, IPCC, and other UN and international policy programs function within that system. SDGs 1 and 2 are especially difficult to make progress towards because poverty and hunger are inherently interlinked yet cannot be resolved together because resource exploitation practices generate hunger by disrupting agriculture, poverty by disrupting livelihoods, or both. Women subsistence farmers are the most vulnerable to these disruptions because agriculture is their livelihood. Sustainability, especially concerning food, is not possible without system-change.

Women farmers working at the intersection of the feminizations of both poverty and agriculture are trapped in the food-poverty-climate nexus generated by practices of global capital. Their work is labor-intensive, under-resourced, needs annual repetition, and can end in catastrophic crop loss because of extreme weather events that leave the family in hunger crisis. The only long-term aspect of farming, given its cyclical processes because of constant consumption of its outputs, is land management aimed at making the job easier, increasing the output, and building climate resilience. Women farmers must act as guardians and caretakers of land over which they have no ownership. We find accordingly that, despite on-going risk to women of losing access to the land they farm, the work itself and women's need and commitment in their role as family caregivers are inherently aimed at sustainability, i.e. at ecosystem health to improve labor conditions and crop yields. While capital and governance work within outdated, destructive frameworks that render hope for a functional future ever more unrealistic, women farmers are already committed to the value of ecosystems services for their livelihood and food security.

We further find that a reliable indicator of transformational change in global economic and governance practices is women farmers' agricultural capacity. Movement away from capital economic and patriarchal governance systems entails addressing climate change, reducing global South-North inequities, and improving the the situation of women whose contributions to their family, community, country, and ecosystem health are substantial and under-valued. It is reasonable to expect that removal of unnecessary, substantial impediments to women's agriculture would increase their food security capacity. Given such removal, this expectation could be tested. In place of such not yet available data sources, we have provided examples that show women, especially as growers, to be innovative agents of change whose strategies and hard work are guided by an inherent and functional conception of sustainability.

Finally, we have examined the goals of women's agriculture as a care practice and found that the logic governing their goals and practices are significantly different from logics aimed at wealth 
accumulation. Their work is cyclical but also understands timelines beyond a single year. As the Chipko women say, 'this forest is our mother's home; we will protect it with all our might,' [71] in understanding they today's forest and field depend on yesterday's farmer, and today's grower has a responsibility to the future, in marked contrast with a logic of conservation based on stocktaking of current reserves in a world where species are disappearing daily and ecosystems are increasingly in crisis. Transformative change means new ways of thinking that reject continuous growth and wealth acquisition in favor of sustainable satisfaction of human needs and meaningful living that aim to leave healthy ecosystems for their children. We find that sustainability approaches that generate conflict amongst their goals are fundamentally flawed, while transformative sustainability strategies hold a promise of success through their holistic, inherent, and integrative vision of reconciliation, care, and respect for diverse needs and interests toward optimal solutions.

\section{Discussion}

Agriculture has been our focus because hunger and food security crises in Africa are pressing humanitarian issues, but systemic transformation cannot be limited to one sector. Human ways of thinking are collective practices of language, concept sharing, and built contexts that inhabitants learn to navigate. None of these things are fixed. Transformative thinking is intentional redirection of ways of thinking by means of concept shift. On way to accelerate concept shift is to look across cultures.

For example, FraFra women farmers in northern Ghana overwhelmingly express a need to act on climate change [9]. Why would they want not want to get rid of the oil that is suffocating the planet in order to make a small group so wealthy that they deny climate change is real and undermine development of renewables in order to continue accumulation of private wealth? These women have very little if any access to that oil, so no dependency on it, and its climate impacts are destroying their food security. Competition as a principle of the logic of capital implies that people are fundamentally greedy and lazy, but women throughout the planet work hard for no money to care for their children, home, crops, animals, and community. Knowledge-systems that exhibit different perspectives are needed at all levels of governance to prompt the transformational change necessary for the sustainability of ecosystems and human practices that enable life.

In closing, this paper warrants some caveats. The point is not to use these women instrumentally to clean up ecosystem messes created by the global North that are harming their food security. Rejecting suggestion that these women have contributions to make to bring about transformative change on the basis that it exploits them is a biased assumption that they cannot speak for themselves about their willingness to participate and lead discussion. Nor is the point to idealize the brutal labor of subsistence farming. It is rather to push for system change that would improve those conditions and address global inequities in living conditions between South and North. For example, shifting capital from a system that gathers wealth for the sake of wealth to a system in which capital is not an end in itself but a means would render distributive justice across the South-North divide more attainable. Also, care practices have not been argued to be inherent to gender but to be a consequence of women's care labor that is gendered by cultural habit but need not be. Indigenous knowledge-systems provide multiple alternatives to Eurocentric gender politics and capital logic. Men and women can and do participate in care practices. Domination of capital 
systems is likewise gender-based on conceptions of masculinity that can be shifted. Transformative change can begin with women's care logics but anyone can think this way. The task is specifically to bring this thinking into global economics and governance in order to make sustainability possible by 2030 .

Author Contributions: conceptualization, T. G.. and E.O. ; methodology, T.G and E.O..; software, T.G..; validation, T.G.; formal analysis, T.G and E.O..; investigation, T.G and E.O..; resources, T.G..; data curation, T.G.; writing-original draft preparation, E.O.; writing-review and editing, T.G.; visualization, T.G..; supervision, T.G..; project administration, T.G..; funding acquisition, n/a.

Funding: Please add: “This research received no external funding”

Conflicts of Interest: "The authors declare no conflict of interest."

\section{References}

1. United Nations Sustainable Development Goals. Transforming our World: The 2030 Agenda for Sustainable Development. United Nations A/Res/70/1. Available online: https://sustainabledevelopment.un.org/content/documents/21252030\%20Agenda\%20for\%20Sustainable\% 20Development\%20web.pdf (accessed on 3 August 2020).

2. United Nations. The Millennium Development Goals Report 2015. United Nations: New York, USA, 2015

3. Sanchez, P. A.; Swaminathan, M. S. Hunger in Africa: the link between unhealthy people and unhealthy soils. Lancet 2005, 365, 442-44.

4. Hall, B.; Garabiles, M. R.; de Hoop, J.; Pereira, A.; Prencipe, L.; Palermo, T. M. Perspectives of adolescent and young adults on poverty-related stressors: a qualitative study in Ghana, Malawi and Tanzania. BMJ 2019, e027047. doi:10.1136/bmjopen-2018-027047.

5. Cotula, L.; Vermeulen, S.; Leonard, R.; Keeley, J. Land grabbing or development opportunity. In Agricultural Investment and International Land Deals in Africa; IIED/FAO/IFAD: London, UK, 2009.

6. FAO. Ghana at a glance. FAO in Ghana, 2020. Available online: http://www.fao.org/ghana/fao-in-ghana/ghana-at-a-glance/en/ (accessed on 28 July 2020).

7. Akayeti, E. Research work on Naara (Early) and Zea (Late) Millets in Ghana. Modern Ghana, Science and Environment, $2019 . \quad$ Available online: https://www.modernghana.com/news/954914/research-work-on-naara-early-and-zea-late-mill. html (accessed on 2 August 2020).

8. Puozaa, D. K.; Jaiswal, S.K.; Dakora, F. D. African origin of Bradyrhizobium populations nodulating Bambara groundnut (Vigna subterranea L. Verdc) in Ghanaian and South African soils. PLoS ONE 2017, 12, e0184943; Available online: https://doi.org/10.1371/journal.pone.0184943 (accessed 2 August 2020).

9. Glazebrook, T. Women and climate change: A case Study from Northeast Ghana. Hypatia 2011, 26, 762-782.

10. World Bank 2020 World Development Indicators. Available online: http://datatopics.worldbank.org/world-development-indicators/ (accessed on 3 August 2020).

11. World Bank. Data for Lower Middle Income, Ghana. Available online: https://data.worldbank.org/?locations=XN-GH (accessed on 3 August 2020).

12. World Food Programme. Comprehensive Food Security \& Vulnerability Analysis: Ghana 2012. Focus on Northern Ghana. Available online: https://documents.wfp.org/stellent/groups/public/documents/ena/wfp257009.pdf (accessed on 3 August 2020).

13. Glazebrook, T. Climate adaptation in the global South: Funding women's farming. In Reinvigorating Eco-Feminism: New Themes and Directions; Phillips, M., Rumens, N., Eds.; Routledge: London, UK, 2015; pp. 111-131.

14. Peng S., Huang; Sheehy, J. E.; Laza, R. C.; Visperas, R. M.; Zhong, X.; Centeno, G. S.; Khush, G. S.; Cassman, K. G. Rice yields decline with higher night temperature from global warming. PNAS 2004, 101, 9971-9975; doi: 10.1073/pnas.0403720101 
15. International Monetary Fund. Republic of Ghana, Ghana Poverty Reduction Strategy: 2003-05; IMF Country Report No. 03/56, March 6 2003; IMF Publication Services: Washington, DC, USA, 2003; Available online: https://www.imf.org/en/Publications/CR/Issues/2016/12/30/Ghana-Poverty-Reduction-Strategy-Paper-163 90 (accessed on 3 August 2020).

16. Social Watch Coalition. National Reports-Ghana: MDGs Remain Elusive. Available online: http://www.socialwatch.org/node/12082 (accessed on 3 August 2020).

17. Waring, M. If Women Counted: A New Feminist Economics; Harper \& Row: New York, NY, USA, 1988.

18. Opoku, E.; Glazebrook, T. (2018) Gender, agriculture, and climate policy in Ghana. Environ. Ethics 2018, 40, 365-80.

19. FAO; IFAD; WFP. The State of Food Insecurity in the World 2015: Meeting the 2015 International Hunger Targets: Taking Stock of Uneven Progress; Food and Agriculture Organization of the United Nations: Rome, Italy, 2015; Available online: http://www.fao.org/3/a-i4646e.pdf (accessed on 28 July 2020).

20. FAO; ECA. Regional Overview of Food Security and Nutrition; Food and Agriculture Organization of the United Nations and United Nations Economic Commission for Africa: Accra, Ghana, 2018; Available online: http://www.fao.org/3/CA2710EN/ca2710en.pdf (accessed on 3 August 2020).

21. IISD Mixed messages on achieving zero hunger in Africa. International Institute for Sustainable Development, $2018 . \quad$ Available online: http://sdg.iisd.org/news/mixed-messages-on-achieving-zero-hunger-in-africa/ (accessed 28 July 2020).

22. International Monetary Fund. Sub-Saharan Africa: The path to recovery. IMF News. 30 October 2017. Available

online: https://www.imf.org/en/News/Articles/2017/10/27/na103017-sub-saharan-africa-the-path-torecovery (accessed on 30 July 2020).

23. ADBG. Africa's economic performance improves in 2017. African Development Bank Group, 2017. Available online: https://www.afdb.org/en/news-and-events/africas-economic-performance-improves-in-201717 424\#: :text=Africa's\%20economic\%20outlook\%20improved $\% 20 \mathrm{in}$, on $\% 20$ Thursday $\% 2 \mathrm{C} \% 2012 \%$ 20October\%202017 (accessed 3 August 2020).

24. Glazebrook T.; Noll, S.; Opoku, E. (2020) Gender Matters: Climate Change, Gender Bias, and Women's Farming in the Global South and North. Agriculture 2020, 10, 267; doi: 10.3390/agriculture10070267

25. FAO. Gender: The Female Face of Farming. Available online: http://www.fao.org/gender/resources/infographics/the-female-face-of-farming/en/ (accessed on 3 August 2020).

26. IPCC WGIIA SP. Part A: Global and sectoral aspects, summary for policymakers. In AR5 Climate Change 2014: Impacts, Adaptation, and Vulnerability. Contribution of Working Group II to the Fifth Assessment Report (AR5) of the Intergovernmental Panel on Climate Change; Field, C.B., Barros, V.R., Dokken, D.J., Mach, K.J.,Mastrandrea, M.D., Bilir, T.E., Chatterjee, M., Ebi, K.L., Estrada, Y.O., Genova, R.C., et al., Eds.; CambridgeUniversity Press: Cambridge, MA, USA; New York, NY, USA, 2014; pp. 1-32. Available online: https://www.ipcc.ch/report/ar5/syr/ (accessed on 3 August 2020).

27. UNDP 2020 Transforming Agriculture: Creating food security while fighting climate change. Available online: https://stories.undp.org/transforming-food-and-agriculture (accessed 3 August 2020).

28. Thompson, P. B. The Agrarian Vision: Sustainability and Environmental Ethics. Lexington: The University Press of Kentucky, 2010.

29. Solow, R. M. Intergenerational equity and exhaustible resources. MIT Working paper number 103, Department of Economics, MIT, 1973. Available online: https://archive.org/details/intergenerationaOOsolo (accessed 30 July 2020).

30. Hartwick, J. M. Intergenerational Equity and the Investing of Rents from Exhaustible Resources. Am. Econ. Rev. 1977, 67, 972-974.

31. Brundtland Report. Our Common Future. Oxford University Press: Oxford, UK, 1987.

32. Glazebrook, T. Letting beings be: An ecofeminist reading of Gestell, Gelassenheit and sustainability. In Heidegger and Technology; Wendland, A., Merwin, C., Hadjioannou, C., Eds.; Routledge: London, UK; 2018; pp. 243-260. 
33. World Tourism Organization. Towards measuring the economic value of wildlife watching tourism in Africa. Briefing paper. 2015. Available online: https://sustainabledevelopment.un.org/content/documents/1882unwtowildlifepaper.pdf (accessed 30 July 2020)

34. Trading economics. South Africa GDP. 2020. Available online: https://tradingeconomics.com/south-africa/gdp (accessed 30 July 2020).

35. Diamond, J. Ecological collapse of past civilizations. Proc. Am. Philos. Soc 1994, 138, 363-370.

36. The National Wildlife Federation. Ecosystem services. $\mathrm{u} / \mathrm{d}$ Available online at: https://www.nwf.org/Educational-Resources/Wildlife-Guide/Understanding-Conservation/Eco system-Services (accessed on 31 July 2020).

37. Report of the Secretary-General, Special edition: progress towards the Sustainable Development Goals. Economic and Social Council 2019 Session. E/2019/68. Available online: Special edition: progress towards the Sustainable Development Goals (accessed August 3 2020).

38. Dawson, N.; Martin, A.; Camfield, L. Can agricultural intensification help attain Sustainable Development Goals? Evidence from Africa and Asia. Third World Q. 2019, 40, 926-946; doi: 10.1080/01436597.2019.1568190.

39. Morse, T. D.; Masuku, H.; Rippon, S.; Kubwalo H. Achieving an Integrated Approach to Food Safety and Hygiene-Meeting the Sustainable Development Goals in Sub-Saharan Africa. Sustainability 2018, 10, 2394; doi:10.3390/su10072394.

40. Somanje, A. N.; Mohan, G.; Lopes, J.; Mensah, A.; Gordon, C.; Zhou, X.; Moinuddin, M.; Saito, O.; Takeuchi, K.. Challenges and Potential Solutions for Sustainable Urban-Rural Linkages in a Ghanaian Context. Sustainability 2020, 12, 507; doi:10.3390/su12020507.

41. Antwi-Agyei, P.; Kpenekuu, F.; Hogarh, J. N.; Obiri-Danso, K.; Abaidoo, R. C.; Jeppesen, E.; Andersen, M. N. Land Use and Land Cover Changes in the Owabi Reservoir Catchment, Ghana: Implications for Livelihoods and Management. Geosciences 2019, 9, 286; doi:10.3390/geosciences9070286.

42. Ngarava, S.; Zhou, L.; Ayuk, J.; Tatsvarei, S. Achieving Food Security in a Climate Change Environment: Considerations for Environmental Kuznets Curve Use in the South African Agricultural Sector. Climate 2019, 7, 108; doi:10.3390/cli7090108

43. Newell, P.; Taylor, O.; Naess, L. O.; Thompson, J.; Mahmoud, H.; Ndaki, P.; Rurangwa, R.; Teshome A. Climate Smart Agriculture? Governing the Sustainable Development Goals in Sub-Saharan Africa. Front Sustain. Food Syst. 2019, 3, 55; doi: 10.3389/fsufs.2019.00055.

44. Jagustovića, R.; Zougmor, R. B.; Kesslera, A.; Coen, J.; Ritsemaa, C. J.; Keesstraa, S.; Reynold, M. Contribution of systems thinking and complex adaptive system attributes to sustainable food production: Example from a climate-smart village. Agric. Syst. 2019, 171, 65-75.

45. Partey, S. T.; Zougmoré, R. B.; Ouédraogo, M.; Campbell, B. M. Developing climate-smart agriculture to face climate variability in West Africa: Challenges and lessons learnt. J. Clean. Prod. 2018, 187, 285-295.

46. Amadua, F. O.; Millera, D. C.; McNamarab, P. C. Agroforestry as a pathway to agricultural yield impacts in climate-smart agriculture investments: Evidence from southern Malawi. Ecol. Econ. 2020, 167, 106443.

47. Kapela, J. Ghana's new oil: Cause for jubilation or prelude to the resource curse. MA, Duke University, Durham, NC, USA, 2019.

48. Kiev, C. W. What Dutch disease is, and why it's bad. The Economist, 5 November 2014. https://www.economist.com/blogs/economist-explains/2014/11/economist-explains-2 (accessed 2 August 2020).

49. Glazebrook, T.; Kola-Olusanya, A. Justice, conflict, capital, and care: Oil in the Niger Delta. Environ. Ethics 2011, 33, 163-84.

50. Maconachie, R. Diamonds, governance and 'local' development in post-conflict Sierra Leone: Lessons for artisanal and small-scale mining in sub-Saharan Africa? Resour. Policy 2009, 34, 71-79.

51. Glazebrook, T.; Story, M. The community obligations of Canadian oil companies: A case study of Talisman in the Sudan. In Corporate Social Irresponsibility: A Challenging Concept; Jones, B., Tench, R., Sun, W., Eds.; Emerald Group Publishing: Bingley, UK; 2012; pp. 231-61.

52. McFerson, H. Governance and hyper-corruption in resource-rich African countries. Third World Q. 2009, 30, 8, 1529-1548.

53. Weinthal, E.; Luong, P. J. Combating the Resource Curse: An alternative solution to managing mineral wealth. Perspect. Politics 2006, 4, 35-53. 
54. The Green Belt Movement. Available online at: http://www.greenbeltmovement.org/ (accessed on 3 August 2020).

55. Matthai, W. Unbowed: A Memoir. Knopf Publishing Group: New York, USA, 2006.

56. Lionesses of Africa. Mariam Lawani, a Nigerian entrepreneur tackling poverty and unemployment through $\quad$ recycling. 92020 May 20 Available http://www.lionessesofafrica.com/blog/2020/5/9/startup-story-of-mariam-lawani (accessed on 31 July 2020).

57. Rao, V. R. Women farmers of India's Deccan Plateau. In Environmental Ethics, 3rd ed.; Schmidtz, D.D., Shahar, D.C., Eds.; Oxford University Press: New York, NY, USA; 2019; pp. 337-343.

58. Kumbamu, A. The agri-food sector's response to the triple crisis: Sustaining local social initiatives in Andhra Pradesh, India. Development 2012, 55, 104-111.

59. Glazebrook, T. What women want: An (eco)feminist in dialogue with John D. Caputo: In Cross and Khôra: Deconstruction and Christianity in the Work of John D. Caputo: Zlomislić, M., Deroo, N., Eds.: Pickwick Publications, Wipf and Stock: Eugene, OR, USA, 2010; pp. 230-58.

60. Petruzzello, M. Chipko movement. Encyclopedia Brittanica. Available online: https://www.britannica.com/topic/Chipko-movement (accessed on 31 July 2020).

61. Gender CC. Side Event: Report on the Gender into Urban Climate Change Initiative. UNFCCC Conference of Parties 23, 2017, Bonn Germany.

62. Gender CC 2020. Stakesholder Workshop in Cambayya Subdistrict, Makassar City. Available online: https://www.gendercc.net/resources/gender-and-climate-news/article.html?tx news pi1\%5Bac tion $\% 5 \mathrm{D}=$ detail\&tx news pi1 $\% 5 \mathrm{Bcontroller} \% 5 \mathrm{D}=\mathrm{News} \& \mathrm{tx}$ news pi1 $\% 5 \mathrm{Bnews} \% 5 \mathrm{D}=117 \& \mathrm{cHa}$ $\underline{\mathrm{sh}=4 \mathrm{c} 65 \mathrm{ff} 9921 \mathrm{f} 2 \mathrm{~d} 807 \mathrm{~d} 3 \mathrm{f} 152776 \mathrm{ac} 548 \mathrm{ac}}$ (accessed on 1 August 2020).

63. Gender CC 2020. Stakeholder Workshop in Buloa Subdistrict, Makassar City. Available online: https://www.gendercc.net/resources/gender-and-climate-news/article.html?tx news pi1\%5Bac tion $\% 5 \mathrm{D}=$ detail\&tx news pi1\%5Bcontroller $\% 5 \mathrm{D}=\mathrm{News} \& \mathrm{tx}$ news pi1 $\% 5 \mathrm{Bnews} \% 5 \mathrm{D}=117 \& \mathrm{cHa}$ $\underline{\text { sh}=4 c 65 f f 9921 f 2 d 807 d 3 f 152776 a c 548 a c ~(a c c e s s e d ~ o n ~} 1$ August 2020).

64. Glazebrook, T. Ecofeminism without borders: The power of method. In Environmental Ethics for Canadians; Williston, B., Ed. 2nd ed. Oxford University Press: Oxford, UK; 2015; pp. 164-171.

65. Riley, C. 22 men own more wealth than Africa's 326 million women, Oxfam says. CNN Business. 20 January 2020. Available online: https://stories.undp.org/transforming-food-and-agriculture (accessed 28 July 2020).

66. Warren, K.. Ecofeminist Philosophy: A western perspective on what it is and why it matters. Rowman and Littlefield; Oxford, UK, 2000.

67. Glazebrook, T. Gynocentric eco-logics. Ethics Environ. 2005, 10, 75-99.

68. Mies, M.; Shiva, V. Ecofeminism. Zed Books: London, UK, 1993.

69. Lowder, S.K.; Skoet, J.; Raney, T. The number, size, and distribution of farms, smallholder farms, and family farms worldwide. World Dev. 2016, 87, 16-29.

70. FAO. The State of Food and Agriculture: Leveraging Food Systems for Inclusive Rural Transformation; Food and Agriculture Organization of the United Nations: Rome, Italy, 2017. Available online: http://www.fao.org/3/a-i7658e.pdf (accessed on 1 August 2020).

71. Singhal, A.; Lubjuhn, S. The Chipko Environmental Conservation Movement Media (India). In Encyclopedia of Social Movement Media; Downing, J. D. H., Ed.; Sage Publications: Los Angeles, CA, USA; 2010; pp. 91-2. 